\title{
Pentingnya Komunikasi Efektif dengan Berbahasa Santun Berbasis Religi Terkait Informasi Wabah Virus di Media Online
}

\author{
${ }^{1}$ Made Dwi Adnjani, ${ }^{1}$ Dian Marhaeni Kurdaningsih, ${ }^{2}$ Choiril Anwar* \\ ${ }^{1}$ Prodi Ilmu Komunikasi, Universitas Islam Sultan Agung, Semarang, Indonesia \\ ${ }^{2}$ Prodi Pendidikan Bahasa Inggris, Universitas Islam Sultan Agung, Semarang, Indonesia \\ *Corresponding Author: \\ Jl. Kaligawe Raya Km 4 Semarang 50112, Indonesia \\ Email: choirilanwar@unissula.ac.id \\ Received: \\ Revised: \\ Accepted: \\ Published: \\ 2 February 2021 \\ 15 April 2020 \\ 15 Mei 2021 \\ 30 June 2021
}

\begin{abstract}
Abstrak
Variatifnya ragam konten media sosial yang berkembang di masyarakat harus bisa dipahami dengan bijak. Karenanya butuh pemahaman yang benar dan baik terkait komunikasi bencana melalui sosialisasi komunikasi efektif dengan penggunaaan bahasa yang santun, melalui pendekatan religi kepada masyarakat. Tujuan diadakannya program pengabdian masyarakat ini adalah agar masyarakat lebih mampu memahami konten media dan bagaimana menanggapinya serta apa yang harus dilakukan ketika menyebarkan informasi yang diterimanya melalui media digital. Oleh karena itu, perlu diadakan sosialisasi komunikasi efektif dengan bahasa santun di media online dengan pendekatan religi di Kelurahan Gedawang Kecamatan Banyumanik Kota Semarang. Sosialisasi dilaksanakan melalui kolaborasi dengan program kemitraan. Dipilih dua mitra yang aktif yaitu Majelis Taklim dan Kampung KB RW 2 yang mampu mengkoordinasikan warga masyarakat dan peduli pada kesejahteraan baik fisik maupun psikis. Hasil dari program pengabdian ini sangat diharapkan mampu membuka wawasan pada masyarakat terutama warga peserta majelis taklim Gedawang Banyumanik dalam berkomunikasi di dunia maya dan memahami beragam konten di media sosial sehingga mereka dapat lebih dewasa dan bijaksana dalam menyikapi hal tersebut.
\end{abstract}

Kata kunci: Komunikasi; santun; religi; media online.

\begin{abstract}
The variety of social media content that develops in society must be understood wisely. Therefore, a correct and good understanding of disaster communication is needed through the sosialization of effective communication with the use of polite language, through a religious approach to the community. The purpose of holding this community service program is so that people are better able to understand media content and how to respond to it and what to do when disseminating some information received through digital media. Therefore, it is necessary to socialize effective communication with polite language on online media with a religious approach in Gedawang, Banyumanik District, Semarang. Socialization is carried out in collaboration with a partnership program. Two active partners were chosen,
\end{abstract}


namely Majelis Taklim and Kampung KB $R W 2$ who were able to coordinate community members and care for their physical and psychological well-being. The results of this community service program are expected to be able to open insights to the community, especially the members of the Gedawang Banyumanik majelis taklim participants in communicating in cyberspace and understanding various content on social media so that they can be more mature and wiser in responding to this.

Keywords: Communication; politeness; religion; online media.

\section{PENDAHULUAN}

Berbagai media sosial yang terus dinamis bermunculan dan berkembang serta digemari masyarakat dengan beragam kontennya harus dapat dipahami dan disikapi dengan bijak. Tak jarang konten yang merebak dan menjadi viral adalah konten-konten yang bermuatan tidak mendidik dan bahkan hoaks. Karenanya butuh pemahaman yang benar dan baik terkait komunikasi bencana melalui sosialisasi komunikasi efektif dengan penggunaaan bahasa yang santun, melalui pendekatan religi kepada masyarakat.

Memang, sebagai makhluk sosial manusia takkan luput dari komunikasi, baik secara verbal maupun non-verbal karena sebagian besar aktivitas manusia dalam sehari berupa komunikasi (Effendy, 2017; Wisman, 2017). Manusia melakukan komunikasi dengan manusia lain dengan berbagai tujuan. Di antara tujuan tersebut adalah menyampaikan informasi. Menurut Miftah (2019), agar terjadi komunikasi efektifyang mana informasi yang disampaikan itu sampai kepada penerima informasi, maka diperlukan suatu pendekatan komunikasi yaitu pendekatan secara ontologis, aksiologis, epistemologis. Salah satu pendekatan aksiologis yang baik dalam berkomunikasi adalah dilakukan dengan bahasa-bahasa yang baik, tepat sasaran, bahasa-bahasa santun yang didasarkan atas nilai-nilai keagamaan.

Sebuah komunikasi dapat berhasil apabila kita mengetahui dan mempelajari unsur-unsur yang terkandung dalam proses komunikasi. Unsur-unsur itu adalah sumber, pesan, saluran atau media dan penerima (Rokhmah \& Anggorowati, 2017). Komunikasi dapat efektif apabila pesan diterima dan dimengerti sebagaimana dimaksud oleh pengirim pesan, pesan ditindaklanjuti dengan sebuah perbuatan oleh penerima pesan dan tidak ada hambatan untuk hal itu (Hardjana, 2003). Komunikasi yang efektif terjadi bila pendengar (penerima berita) menangkap dan menginterpretasikan ide yang disampaikan dengan tepat seperti apa yang dimaksud oleh pembicara (pengirim berita).

Sementara itu, kesantunan dalam berbahasa tercermin dalam tata cara berkomunikasi lewat tanda verbal atau tatacara berbahasa. Ketika berkomunikasi, sudah seharusnya kita tunduk pada norma-norma agama dan budaya yang berkembang dalam masyarakat, tidak hanya sekadar menyampaikan ide yang kita pikirkan. Tatacara berbahasa harus sesuai dengan unsur-unsur agama dan budaya yang ada dalam masyarakat tempat hidup dan dipergunakannnya suatu bahasa dalam berkomunikasi (Mislikhah, 2020). Pemakaian bahasa sebagai alat komunikasi dipengaruhi oleh faktor sosial (status sosial, jenis kelamin, umur, tingkat pendidikan, tingkat ekonomi dan 
sebagainya) dan faktor situasional (siapa yang berbicara dengan bahasa apa, kepada siapa, kapan, di mana, mengenai hal apa, dalam situasi yang bagaimana, apa jalur yang digunakan, ragam bahasa mana yang digunakan, serta tujuan pembicara (Nababan, 1986).

Kesantunan berbahasa ini sangatlah penting karena dapat membentuk karakter sebuah bangsa (Kurniadi et al., 2018). Apabila kita ingin bangsa memiliki karakter dan peradaban serta kepribadian yang baik, maka kita musti mengembangkan dalam masyarakat kesantunan dalam berbahasa, apalagi bila bahasa tersebut dilandaskan pada nilai-nilai religious yang menjunjung tinggi nilai-nilai kesopanan (tawadhu). Religius sebagai salah satu nilai dalam pendidikan karakter dideskripsikan oleh Kemendiknas (2010) sebagai sikap dan perilaku yang patuh dalam melaksanakan ajaran agama yang dianut, toleran terhadap pelaksanaan ibadah agama lain, dan hidup rukun dengan pemeluk agama lain. Selain itu, nilai religious merupakan peghayatan dan implementasi dari ajaran agama dalam kehidupan sehari-hari, tidak hanya sekadar pengetahuan saja (Naim, 2011).

\section{Analisis Situasi}

Wilayah Kelurahan Gedawang masuk kategori daerah pinggiran. Sebagian masyarakat memiliki mata pencaharian sebagai karyawan perusahaan di garmen, roti, mie dan sebagainya. Sebagiannya lagi adalah petani, mereka memiliki lahan yang terhampar di lereng pengunungan tepatnya di sebelah timur jalan tol Semarang Bawen. Di antara mereka adalah ibu rumah tangga yang bekerja di rumah. Mereka memiliki home industry seperti membuat kue, camilan, kerupuk dan lauk pauk yang dikemas dan dijual di masyarakat sekitar. Rata-rata para orang tua di kelurahan Gedawang memiliki kegiatan kerohanian yang khas seperti pengajian malam Jumat untuk para bapak dan malam Senin untuk para ibu. Ada beberapa kegiatan lagi di hari Sabtu dan hari khusus lainnya seperti hari besar keislaman. Mereka para orang tua juga aktif dalam kegiatan sosial masyarakat seperti PKK untuk para ibu dan bulan jumpa untuk bapak, belum lagi ada kegiataan ritual adat yang sudah rutin dijalankan di masyarakat seperti ritual Apitan.

Anak-anak mereka yang tumbuh menjadi remaja adalah anak siswa sekolah yang aktif dalam berbagai kegiatan seperti hobi, olah raga, seni rebana dan lain-lain. Untuk mendukung aktivitas para orang tua Mitra dan remaja ini didukung oleh teknologi gawai yang sangat dinamis dan praktis disertai kelengkapan aplikasi. Gawai yang mereka miliki adalah smartphone dengan kesempurnaan fasilitas mereka rata-rata sudah memiliki teknologi pendukung tersebut. Ketika konten terkait wabah virus covid-19 menghiasi media online, banyak sekali konten-konten yang tidak benar dan salah informasi sehingga muncul persepsi negatif yang mempengaruhi perilaku masyarakat dan secara psikologis memengaruhi dalam menanggapi informasi tersebut. Fakta menunjukkan bahwa tindakan yang dilakukan di beberapa tempat di Jawa Tengah seperti penolakan untuk diperiksa, pasien tidak jujur dan penolakan jenazah, menunjukkan adanya ketidakmampuan untuk memahami virus covid-19. Komunikasi menjadi tidak efektif ketika permasalahan bertambah dengan adanya kelompok masyarakat yang menanggapi percakapan di media online dengan bahasa yang kurang santun, sehingga menumbuhkan ketegangan, tidak enak hati, pakewuh, mengabaikan 
tatanan hierarki di masyarakat dan menimbulkan syak-wasangka hanya karena salah bahasa. Secara psikologis dan sosial ke depan tentu ini bisa menjadikan masalah. Beberapa masalah yang lebih penting adalah variatifnya konten media harus bisa dipahami dengan bijak. Sehingga butuh pemahaman yang benar dan baik terkait komunikasi bencana melalui sosialisasi komunikasi efektif dengan penggunaaan bahasa yang santun, melalui pendekatan religi kepada masyarakat. Hal ini agar masyarakat lebih mampu memahami konten media dan bagaimana menanggapinya serta apa yang harus dilakukan ketika menyebarkan informasi yang diterimanya melalui media digital.

Dipilihnya dua mitra yang aktif yaitu Majelis Taklim dan Kampung KB RW 2 adalah karena Ketua Majelis Taklim dan Juga Ketua Kampung KB RW2 mampu mengkoordinasikan warga masyarakat dan peduli pada kesejahteraan baik fisik maupun psikis. Di samping itu juga kampung $\mathrm{KB}$ ini sering menjuarai lombadi tingkat kota Semarang. Dengan sosialisasi berbahasa yang santun dan religius maka Iptek yang ditransfer dalam kegiatan ini adalah metode sosialisasi komunikasi dengan berbahasa santun melalui media online dengan pendekatan religi yang dilaksanakan pada masyarakat.

Masyarakat asli Gedawang sangat memegang nilai-nilai budaya setempat seperti adat sedekah bumi, peringatan hari besar agama yang dirayakan secara tradisional. Kondisi ini berbeda dengan tradisi para pendatang yang lebih menyukai kegiatankegiatan modern seperti olah raga, kerja bakti dan lainnya. Kegiatan religi yang ada di Kelurahan Gedawang biasanya berlangsung semarak, masing-masing RT memiliki kajian majelis taklim setiap minggunya, dan beberapa masjid besar ramai oleh kegiatan religi. Melalui pendekatan religi inilah tim pengabdian masyarakat Fakultas Bahasa dan Ilmu Komunikasi melakukan sosialisasi komunikasi efektif melalui berbahasa yang santun dalam menanggapi dan melontarkan ujaran di sosial media.

Program ini menciptakan ketrampilan bagi masyarakat dalam transfer pengetahuan untuk lebih memahami sifat informasi di media online dan memahami cara berkomunikasi serta berbahasa santun dalam pemanfaatan media online. Didukung perubahan mindset tentang manfaat media digital diharapkan mampu meningkatkan soft skill sehingga masyarakat menjadi lebih kreatif dengan ide-ide baru untuk konten yang lebih positif. Hasil pendampingan ini akan ditindaklanjuti dalam riset berbasis kegiatan pengabdian masyarakat dan didesiminasi dalam jurnal akreditasi nasional ber-ISSN, publikasi media massa, poster dan bila keadaan sudah memungkinkan maka hasil sosialisasi ini akan dipresentasikan di konferensi nasional dan diharapkan bisa setidaknya dipublikasikan di prosiding ber ISBN.

\section{METODE PELAKSANAAN}

Tahap pertama yang dilakukan dalam pendampingan ini Tim bersilaturahmi kepada ketua Majelis Taklim Bina Ilmu dan anggota kelompok masyarakat pelaku dan penggiat majelis taklim di Gedawang. Diadakan dialog tentang kondisi dan permasalahan serta harapan kelompok masyarakat terkait informasi wabah virus. Tim menawarkan solusi. Tim menginformasikan tentang pentingnya sosialisasi komunikasi efektif dengan bahasa santun dan etika komunikasi terkait informasi tentang wabah 
virus corona di media online dalam meningkatkan pengetahuan, pemahaman dan ketrampilan pada masyarakat.

Tim dan ketua majelis taklim serta anggota kelompok membuat kesepakatan jadual pertemuan dan anggota menyatakan komitmen untuk selalu hadir dalam pertemuan-pertemuan yang sudah disepakati. Kemudian tim terjun ke masyarakat mendata sekali lagi detail permasalahan mitra kepada anggota kelompok. Pada pertemuan pertama tim mengadakan sosialisasi tentang program.

Anggota kelompok mendapatkan motivasi dan pengetahuan serta ketrampilan komunikasi dan berbahasa santun dengan basis religi di media online melalui berbagai macam kegiatan sosialisasi. Selain memberikan sosialisasi tim juga melakukan dialog berkelanjutan dengan pendampingan periodik. Tim mendatangi anggota masyarakat dan melakukan konsultasi berkaitan dengan praktik komunikasi dan berbahasa santun melalui pendekatan religi sebagai basis kehidupan bermasayarakat di Gedawang.

\section{HASIL DAN PEMBAHASAN}

Kegiatan pengabdian masyarakat yang dilaksanakan di Majelis Taklim Bina Ilmu Kelurahan Gedawang Banyumanik ini sudah berlangsung pada September 2020. Kegiatan dilaksanakan secara offline di rumah kediaman Ketua Majelis Taklim, ibu Istianah Afif, tepatnya di RT 02 RW 02 Gedawang. Kegiatan ini memanfaatkan pertemuan yang sudah ada, yaitu pertemuan kajian Keislaman yang sudah berlangsung secara rutin dan sempat terhenti karena ada wabah nasional covid-19. Di sela mewabahnya virus tersebut dan dirasakannya situasoi lebih konduksif maka diadakan lagi kajian rutin. Namun dengan merbaknya kembali virus covid sementara terdengar kabar beberapa anggota terstatus reaktif dan suspect maka hingga hari ini kajian keislaman masih dihentikan.

Kegiatan ini dihadiri 85 anggota. Acara dibuka oleh ibu Istianah dengan didahului dengan membaca doa pembuka. Selanjutnya acara diserahkan kepada tim dari Unissula untuk mengisi. Tim Unissula membuka acara dengan kalimat pengantar menyampaikan maksud dan tujuan dilaksanakannya acara pengabdian masyarakat. Adapun tujuan dari kegiatan adalah tersosialisasinya komunikasi efektif dengan berbahasa santun di media online berbasis religi. Acara berikutnya adalah inti acara berupa pemaparan materi tentang Sosialisasi Komunikasi efektif, dengan berbahasa santun berbasis religi terkait informasi wabah virus di media online. 


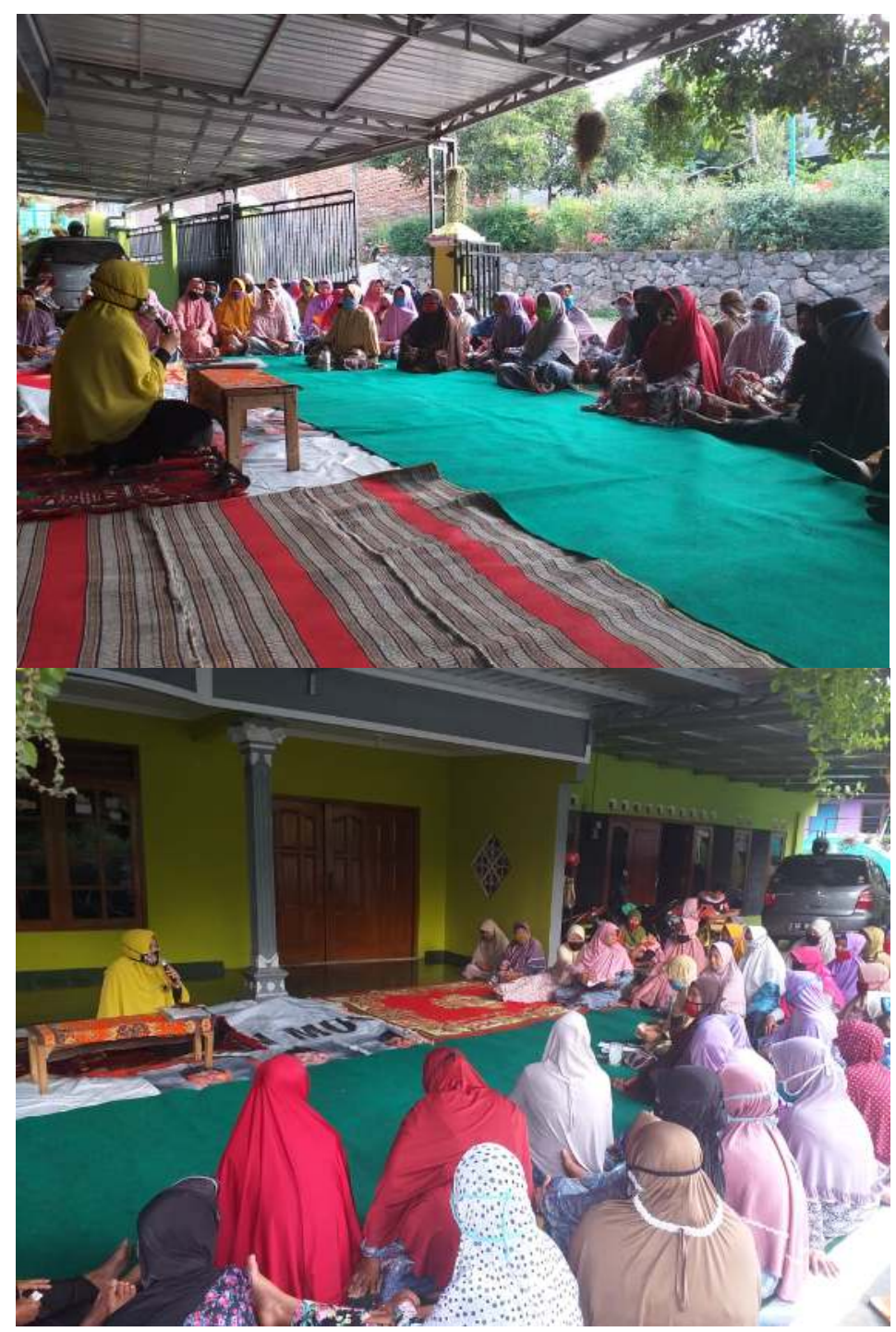

Gambar 1. Sosialisasi tentang Komunikasi Berbahasa Santun Berbasis Religi di hadapan peserta Majelis Taklim Gedawang Banyumanik

Kegiatan ini dilatarbelakangi dengan maraknya informasi wabah virus di media online di masa pandemic covid 19 di tahun 2020. Informasi yang dimaksud terutama informasi wabah seperti pemahaman covid atau corona, info pencegahan dari berbagai sumber, dan solusi yang ditawarkan dari berbagai kalangan maupun disiplin ilmu. Perspektif yang berbeda dalam menanggulangi covid ini mendatangkan berbagai tanggapan dari masyarakat.

Salah satunya adalah portal media sosial Whatshapp Group yang banyak dipakai untuk berbagi informasi di kalangan anggota. Informasi yang dibagikan menciptakan banyak tanggapan. Disinilah kadang muncul perbedaan pendapat. Ada beberapa kriteria anggota grup dalam pemahaman ilmu komunikasi kelompok. Mereka yang disebut anggota aktif, yaitu anggota yang sering membagi infomasi dan menanggapi pesan, anggota kurang aktif yaitu anggota yang suka berbagi pesan saja tetapi jarang menanggapi informasi, anggota netral yang tidak pernah menanggapi pesan, anggota 
partisipatif yaitu anggota yang muncul untuk berpartisipasi saja jika ada moment penting dan anggota pasif yang hanya tercantum sebagai anggota tetapi tidak pernah menanggapi pesan.

Anggota grup majelis taklim ini cukup aktif dalam menanggapi berbagai informasi yang terus mengalir. Informasi anggota grup biasanya seputar konten kajian keislaman, informasi penting tentang jadwal taklim dan informasi untuk silaturrahim. Namun seiring masa pandemic, maka informasi wabah virus menjadi domenar untuk dibagi dalam grup ini. Meski anggota tergabung dalam grup majelis taklim yang pada prinsipnya anggota sudah memiliki satu visi untuk mencari ilmu dan beribadah kepada Allah SWT, namun pada praktiknya perbedaan-perbedaan tersebut masih saja terjadi.

Persepsi covid itu sendiri yang dipahami oleh masyarakat dengan berbagai macam sudut pandang seperti:

a. Covid 19 atau Corona adalah sejenis penyakit flu biasa jadi tidak perlu panik

b. Covid 19 adalah menyakit kodrat dimana orang-orang yang ditakdirkan terjangkit saja yang bias terjangkiti

c. Covid 19 adalah virus ciptakan Allah SWT jadi kalau ingin terbebas maka hendaklah kita mendekatkan diri pada Allah SWT

d. Covid 19 adalah konspirasi politik dunia yang disengaja untuk kepentingan pembelian vaksin kepada negara pencipta vaksin

e. Covid 19 adalah peristiwa wabah dan Tim medis adalah garda terdepan dalam menanggulanginya

f. Covid 19 adalah peristiwa psikologis, sehingga dipercaya hanya orang-orang yang memiliki jiwa yang labil saja yang dapat terjangkiti virus tersebut.

Informasi terkait covid yang dibagikan dengan mobilitas yang tinggi di grup media sosial akhirnya mendatangkan beberapa macam tanggapan yang pada umumnya terjadi sebagai efek di antaranya wujud tanggapan tersebut adalah:

a. Setuju dengan konten yang dibagi oleh salah satu anggota grup

b. Setuju dengan mengomentari sesuai argumentasi mereka

c. Tidak berkomentar

d. Tidak setuju dengan menunjukan beberapa alasan sesuai argumentasi

e. Tidak setuju dengan memberi informasi yang dinilai lebih kredibel

f. Tidak setuju dan terjadi perbedaan dalam argumentasi dan saling memberi alasan pembenaran dari sudut pandang yang berbeda.

g. Terjadi polemik atau perselisihan pendapat di media sosial.

Permasalahnnya adalah ketika perbedaan semakin menguat dan menimbulkan rasa tidak nyaman dalam berkomunikasi karena terjadi perbedaan persepsi maka muncullah komunikasi yang kurang santun. Sedangkan kelompok majelis taklim adalah kelompok religi yang terikat nilai-nilai keagamaan yang kuat. Ketidaksantunan ini dapat menimbulkan salah sangka atau miscommunication, sehingga menciptakan komunikasi yang tidak efektif. 
Sehingga pemateri melakukan sosialisasi komunikasi efektif memulai dengan menggali dari akar permasalahan. Jadi tidak menciptakan ketrampilan komunikasi namun lebih mendasar lagi adalah menciptakan bagaimana komunikasi di majelis taklim tetap efektif dengan menggunakan basis religi. Bagaimana cara mengungkapakan komunikasi yang baik dan santun agar komunikasi tetap efektif.

Kegiatan akhirnya dilakukan dengan memilih model sosialiasi yang tercipta dari interaksi antara tim dengan mitra pengabdian. Berupa menciptakan komunikasi efektif berbasis religi. Tim bertugas menggali bagaimana cara yang santun berkomunikasi bersumber dari nilai-nilai keislaman. Al-Quran sudah memberikan petunjuk bagaimana berkomunikasi dengan dilandasi akhlak yang mulia.

Islam mengajarkan untuk berkomunikasi dengan fasih (Qoulan Baligha): berkomunikasi sebaiknya dengan santun dan harus selalu mempertimbangkan kepada siapa kita berkomunikasi, siapa mitra berkomunikasi atau siapa segmen yang dituju. Hendaklah seorang muslim mampu berkomunikasi dengan bahasa kaumnya. Karena anggota majelis taklim dari latar belakang sosial dan ekonomi yang berbeda. Seperti istri TNI, pekerja pabrik, pendidik, pedagang warung, petani dan lainnya.

Nilai Islam berikutnya mengajarkan berkomunikasi dengan benar, berlandaskan fakta dan tidak berdusta. Prinsip Qoulan Sadidan adalah solusi menciptakan komunikasi yang efektif tanpa prasangka sehingga terjadi rasa saling percaya. Prinsip Qoulan Makrufan, Komunikasi yang baik, Qoulan Layyinan, berkomunikasi dengan perkataan yang mulia juga perlu diciptakan.

Solusi permasalahan mitra lainnya adalah dengan menjaga silaturrahim dalam berkomunikasi, mengingat grup dibentuk dengan tujuan untuk sarana komunikasi dan silaturrahim. Grup adalah kepanjangan silaturrahim mitra di media online untuk menyampaikan informasi-penting terkait tema kajian, rencana kegiatan dan program program majelis taklim lain-lain.

Membangun persepsi yang sama antar anggota grup juga merupakan solusi karena bagaimanapun anggota sudah terikat dengan visi yang sama untuk beribadah dan mencari ilmu bersama. Ada benang merah yang menyatukan anggota kelompok dalam sebuah wadah majelis taklim. Menciptakan komunikasi yang kredibel adalah salah satu alternative agar anggota jangan mudah percaya pada informasi yang tidak jelas sumbernya karena informasi tersebut bisa saja menyesatkan.

Menjaga perilaku tidak melakukan klicking monkey (Membagikan informasi tanpa dibaca dan dipahami kebenarannya terlebih dahulu). Sebelum berbagi hendaklah anggota melakukan cek dan ricek agar tidak terperdaya dengan informasi hoack yang menyesatkan dan merugikan. Termasuk dalam perilaku ini adalah peraya begitu saja informasi yang meneror dan informasi palsu dari pihak yang ingin berbuat kriminal.

\section{Umpan Balik dari Mitra}

Tim pengabdian menemukan fenomena unik berkaitan umpan balik mitra. Diawali dengan fokus perhatian pada perbedaan tanggapan pada pesan media yang sering tidak 
dapat dihindari. tanggapan yang dirasa tidak nyaman dan menimbulkan rasa tidak enak di kehidupan nyata. Kemudian pembahasan materi meluas yang seharusnya focus kepada sosialisasi komunikasi efektif di media sosial berbasis religi melebar kepada materi-materi pesan bertujuan kriminalitas di media online. Di antara tanggapan tersebut adalah:

a. Kesaksian mitra terjadi perbedaan pendapat dalam menanggapi informasi di media sosial.

b. Kesaksian mitra yang pernah mendapatkan informasi dari temannya tentang penipuan sehingga terjadi kerugian materi.

c. Kesaksian mitra tentang informasi Hoax informasi data jumlah korban dan pasien covid.

d. Kesaksian mitra tentang informasi penipuan dengan informasi palsu seperti informasi kecelakaan yang menimpa anggota keluarga dan lainnya.

Selanjutnya diinformasikan bahwa tidak semua mitra dalam majelis taklim dapat aktif menanggapi informasi di media sosial, karena terkendala usia yang sudah sepuh sehingga tidak mampu mengimplementasikan perangkat internet bahkan beberapa anggota tidak memiliki perangkat atau tidak tersedia fasilitas perangkat media sosial.

Kondisi lainnya adalah belum memiliki kecakapan berkomunikasi, karena tingkat pendidikan yang tidak sama dan juga perbedaan usia yang cukup signifikan kadang terjadi ketidak samaan makna atau miscommunication. Komunikasi yang sering disampaikan kadang menggunakan gaya komunikasi sehari-hari dan mereka tidak menyadari bahwa dalam grup terdapat banyak orang yang sedang menyimak.

Ditinjau dari pola komunikasi maka komunikasi bersifat non-sentralistik, atau sering disebut pola menyebar meskipun pengaruh pimpinan masih berperan tetapi tidak cukup mendominasi. Di era media online posisi ketua majelis dan pengisi materi sudah sangat demokratis. Mitra merangkul anggota yang memiliki keinginan kuat untuk bergaul, bersosial dan memiliki perhatian terhadap informasi dari luar seperti kegiatan sosialisasi ini.

Mitra juga menunjukkan eksistensi berkomunikasi di media sosial dengan menanggapi informasi baru, apapun tanggapannya yang terpenting ada keinginan aktif untuk bercerita tentang pengalaman sendiri maupun pengalam orang lain.

\section{KESIMPULAN}

Dari hasil program ini dapat ditarik kesimpulan bahwa sebuah komunikasi akan berhasil apabila kita mengetahui dan mempelajari unsur-unsur yang terkandung dalam proses komunikasi: Komunikasi dapat efektif apabila pesan diterima dan dimengerti sebagaimana dimaksud oleh pengirim pesan, pesan lalu ditindaklanjuti dengan sebuah perbuatan oleh penerima pesan dan tidak ada hambatan untuk hal itu. Selain itu, komunikasi akan efektif bila pendengar menangkap dan menginterpretasikan ide yang disampaikan dengan tepat seperti apa yang dimaksud oleh pembicara. Sedangkan 
kesantunan dalam berbahasa tercermin dalam tata cara berkomunikasi lewat tanda verbal atau tatacara berbahasa. Ketika berkomunikasi, sudah seharusnya kita tunduk pada norma-norma agama dan budaya yang berkembang dalam masyarakat, tidak hanya sekadar menyampaikan ide yang kita pikirkan. Tatacara berbahasa harus sesuai dengan unsur-unsur agama dan budaya yang ada dalam masyarakat tempat hidup dan dipergunakannnya suatu bahasa dalam berkomunikasi Pemakaian bahasa sebagai alat komunikasi dipengaruhi oleh faktor sosial dan faktor situasional. Selanjutnya, kesantunan berbahasa dalam komunikasi di media sosial sangat diperlukan dalam upaya mengurangi kesimpangsiuran informasi yang berkembang di dalam masyarakat. Sebab, bagaimanapun juga, kesantunan berbahasa sampai kapan pun sangatlah penting karena dapat membentuk karakter sebuah bangsa, apalagi bila bahasa tersebut dilandaskan pada nilai-nilai agama yang menjunjung tinggi nilai-nilai kesopanan (tawadhu). Selain itu, bahasa adalah citra diri kita, perwujudan dari pikiran dan tindakan kita.

\section{UCAPAN TERIMA KASIH}

Rasa syukur dan ucapan terima kasih yang tiada terhingga kepada pihak-pihak yang memudahkan terselenggaranya kegiatan pengabdian kepada masyarakat ini: Universitas Islam Sultan Agung melalui Lembaga Penelitian dan Pengabdian Masyarakat (LPPM) dengan program-program dan bantuan dananya yang memudahkan dosen mengadakan kegiatan pengabdian kepada masyarakat, juga kepada rekan-rekan dosen Fakultas Bahasa dan Ilmu Komunikasi Unissula serta warga masyarakat Gedawang Banyumanik yang berkenan membantu dan mendukung diadakannya kegiatan di wilayah tersebut.

\section{DAFTAR PUSTAKA}

Effendy, O. U. (2017). Ilmu Komunikasi Teori dan Praktek. PT. Remaja Rosdakarya.

Hardjana, A. M. (2003). Komunikasi Interpersonal dan Intrapersonal. Kanisius.

Kemendiknas, R. I. (2010). Desain Induk Pendidikan Karakter.

Kurniadi, F., Hilaliyah, H., \& Hapsari, S. N. (2017). Membangun Karakter Peserta Didik Melalui Kesantunan Berbahasa. Aksiologiya: Jurnal Pengabdian Kepada Masyarakat, 2(1), 1-7.

Miftah, M. (2019). Strategi komunikasi efektif dalam pembelajaran. Jurnal Teknodik, 12(2), 084-094.

Mislikhah, S. (2020). Kesantunan berbahasa. Ar-Raniry, International Journal of Islamic Studies, 1(2), 285-296.

Nababan, P. W. J. (1986). Sosiolinguistik: Suatu Pengantar. PT Gramedia.

Naim, N. (2011). Dasar-Dasar Komunikasi Pendidikan. Ar-Ruzz Media. 
Indonesian Journal of Community Services

Volume 3, No. 1, May 2021

http://jurnal.unissula.ac.id/index.php/ijocs

DOI: http://dx.doi.org/10.30659/ijocs.3.1.97-107

Rokhmah, N. A., \& Anggorowati, A. (2017). Komunikasi efektif dalam praktek kolaborasi interprofesi sebagai upaya meningkatkan kualitas pelayanan. JHeS (Journal of Health Studies), 1(1), 65-71.

Wisman, Y. (2017). Komunikasi efektif dalam dunia pendidikan. Jurnal Nomosleca, 3(2). 